\title{
"My happiest time" or "my saddest time"? The spatial and generational construction of marriage among youth in rural Malawi and Lesotho
}

\author{
Nicola Ansell $^{1}$ | Flora Hajdu $^{2}$ | Lorraine van Blerk $^{3}$ | Elsbeth Robson ${ }^{4}$
}

\author{
${ }^{1}$ Social and Political Sciences, Brunel \\ University, Uxbridge, UK \\ ${ }^{2}$ Swedish University of Agricultural \\ Sciences, Uppsala, Sweden \\ ${ }^{3}$ University of Dundee, Dundee, UK \\ ${ }^{4}$ University of Hull, Hull, UK \\ Correspondence \\ Nicola Ansell \\ Eamil: nicola.ansell@brunel.ac.uk
}

Funding information

ESRC-DFID, Grant/Award Number: RES167-25-0167

\begin{abstract}
Marriage among African teenagers is currently a central focus of campaigns by UN agencies and international NGOs. Yet marriage has received only limited attention from geographers and has largely escaped the attention of geographers of youth. In this paper we explore the relational geographies of age that underlie young people's motivations for, and experiences of, marriage in two rural African settings with differing marriage practices: matrilocal southern Malawi and patrilocal Lesotho. We draw on participatory research activities and life history interviews conducted with 80 people aged between 10 and 24 years old. While the young people's attitudes and experiences were varied and complex, starkly different accounts emerged from the two settings. In particular, young women in Lesotho offered very negative assessments of marriage, while those in Malawi were very much more positive. Through these examples, we highlight how young people's marriage choices and experiences are relationally produced. Decisions about whether, when and whom to marry reflect socially entrenched expectations concerning generational allocations of resources, labour and responsibilities, which intersect with contemporary social and economic processes including poverty, unemployment, land scarcity and AIDS. Experiences of marriage, too, are produced through practices that are spatially structured and contextually situated in relation to socio-economic conditions. Thus marriage, as a "vital conjuncture" in young people's lives, plays a key role in the relational construction of individual lifecourses and in (re)constructing relationships of age, gender and, especially, generation.
\end{abstract}

\section{K E Y W O R D S}

generation, lifecourse, marriage, relationality, southern Africa, vital conjuncture

\section{1 | INTRODUCTION}

In rural southern Africa marriage is very significant for young people. This significance became apparent as we commenced data collection for a project exploring the impacts of AIDS on livelihoods in young people's transitions to adulthood in Lesotho and Malawi. Working in one village in each country, we invited around 30 people aged between 10 and 24 years old to engage in a series of participatory activities. We divided the volunteers into four groups based on age (10-17 and 18-24) and gender, but suggested they move to a different group if they thought that would be more comfortable.

This is an open access article under the terms of the Creative Commons Attribution License, which permits use, distribution and reproduction in any medium, provided the original work is properly cited.

The information, practices and views in this article are those of the author(s) and do not necessarily reflect the opinion of the Royal Geographical Society (with IBG).

(C) 2017 The Authors. Transactions of the Institute of British Geographers published by John Wiley \& Sons Ltd on behalf of Royal Geographical Society (with the Institute of British Geographers). 
Immediately, in both communities, the young women reorganised themselves based on whether or not they were married, a small number switching in each direction between the age-based groups. In Lesotho, the young married women named their group "lilala", referring to the blankets that women wear when they are married. The significance of marriage socially, spatially and culturally for young people's lives and lifecourses emerged repeatedly throughout the research.

Marriage is indeed important. In many societies, most people marry during their teenage years. When, where and whom a young person marries can have profound implications. It ties the histories and prospects of one individual to another (and their family) and shapes and constrains their life chances. It is not only young people who confer on it a deep significance, but increasingly also global institutions, particularly in relation to "child marriage" (see Girls Not Brides, 2016; UNICEF, 2014).

Given this prominence, it is surprising how little research has been undertaken into young people's marriage decisions or their perceptions of its impacts in their lives. While geographers have grown increasingly attentive to young people's voices, geographers of youth have hitherto largely neglected the topic. ${ }^{1}$ Yet marriage is inherently geographical (it is constructed differently in different places and usually entails spatial mobility). Moreover, the concepts youth geographers work with, such as identity, intergenerationality and vital conjunctures, can advance understanding of the role marriage plays, not only in young people's lifecourses but in broader social and economic change.

In this paper, we build on recent conceptual developments in the relational geographies of age and generation to advance understanding of the role of marriage in southern African contexts. We explore how marriage takes place within, and cements, social relations that are structured by power-laden discourses of age, gender and especially generation. These relations render marriage an appropriate or unavoidable course of action for some young people at particular junctures in their lifecourses and also shape its consequences for their wellbeing. We further show that it is through these relationalities that marriage as an institution both responds and contributes to the contingencies of social and economic change.

The next section of the paper considers the approaches geographers have taken to the study of marriage and contributions of other disciplines. We then outline our conceptual approach, building on relational geographies of age and generation. We consider how marriage is contextually produced and productive of social and economic relations in (patrilineal, patrilocal) rural Lesotho and (matrilineal, matrilocal) southern Malawi. After describing the research methods, we examine the varied motivations for marriage expressed by young people and their experiences of early married life, considering the ways in which these are shaped by and shape relations of age, gender and generation and their place in the lifecourse. We conclude by considering the implications for relational geographies of age, and for campaigns to eradicate child marriage that are based on universalist notions of marriage that neglect the nuances of cultural, social and economic aspects of marriage decisions.

\section{2 | THEMATIC AND CONCEPTUAL APPROACHES TO THE GEOGRAPHIES OF MARRIAGE}

Marriage has long been a category of analysis, if not an object of study, in geographical research. The availability of demographic data that references marriage lends itself to statistical modelling. Geographers have explored spatial patterns and trends in marriage, comparisons of married and unmarried individuals, correlates of age at marriage, and associations between marriage and migration (e.g., Coleman \& Haskey, 1986). These quantitative approaches, which view marriage as a self-evident, undifferentiated phenomenon, characterise many recent studies from diverse disciplines focusing on early marriage. Recent reports from Oxford University's Young Lives project (Favara et al., 2016; Pankhurst et al., 2016; Roest, 2016), for instance, identify spatial patterns and risk factors for early marriage in Peru, Ethiopia and India. Others have investigated how early marriage correlates with various negative outcome indicators (e.g., Delprato et al., 2015; Maswikwa et al., 2015).

In the 1990s work by geographers and others began to link changing marriage practices with broader historical trends. Many focused on the impacts of globalisation-related labour market changes. In various settings, women's employment has increased their mobility, allowed them to socialise with men outside marriage, weakened their kinship networks and brought independent incomes, enabling new patterns of cohabitation and marriage (Balabdaoui et al., 2001; Fan \& Li, 2002; Safa, 1999; Tiano \& Ladino, 1999). More recently, a proliferation of geographical work has explored how transnational marriages are negotiated, experienced and governed (e.g., Mohammad, 2015; Yeoh et al., 2014; Zhang et al., 2015).

Changing employment patterns are not alone in reshaping marriage. Lengthening formal education is associated with changing marriage patterns in many societies (Shapiro \& Gebreselassie, 2014; Torabi et al., 2013). Yet this is not available to all. Roest's (2016) Young Lives report links early marriage in India with structural factors including inequitable access to health and education services as well as social expectations around early childbearing and patriarchal norms concerning the role and value of girls in society. Much research has indicated that marriage is used strategically to manage economic pressures. As 
Archambault argues, marriage should be understood "not as a relic of tradition and malicious patriarchy but, rather, as a contemporary adaptation to livelihood insecurity" (2011, p. 632). It is often a family strategy to address poverty (Morrow \& Crivello, 2015). In Java in the 1920s, many Malay parents married their daughters early to attract energetic young men into their family networks for economic gain (Ong, 2010). In China, some disadvantaged women marry men from "better" rural areas enabling them to achieve social and economic mobility through migration (Fan \& Huang, 1998). In Tanzania, Kudo (2015) found that women would relocate at marriage to benefit from a favourable land tenure system.

Beyond geography, anthropologists and economists have understood marriage not just as a practice mobilised by individuals and communities to serve their own economic interests, but as an institution that plays an instrumental societal role (e.g., Levi-Strauss, 1969). In Bangladesh, White observes, "marriage is not only concerned with individuals, or even couples or families. It is a core social institution, which both materialises and symbolises the underlying moral order" (2017, p. 258). Marriage facilitates social reproduction (Hunter, 2016). Kandiyoti (1988) has described it as a patriarchal bargain, cementing women's interest in accepting power relations that favour men. White (2017) explains how the increasing scale and prevalence of dowry payments in Bangladesh both stems from and contributes to economic change and its gendered impacts. Transfers of cash and consumer goods, funding of higher education and securing of job opportunities for young men relate to diminishing employment opportunities in the country's neoliberal export economy, alongside increasing pressure for market engagement and conspicuous consumption. Dowry payments also fuel the growth of non-formal economic exchanges, enabling young men to establish themselves as economic actors.

Marriage clearly cannot be understood in purely functionalist terms or as a deterministic product of social and economic processes (Ong, 2010). Affect and emotion are important, albeit entangled with power relations (Morrison et al., 2012). Ideologies of love are used in Africa, as elsewhere, to elaborate generational distinctions and reimagine gender relations (Thomas \& Cole, 2009). Romantic love is commonly associated with generational conflict and young people seeking freedoms (Hunter, 2016). Yet "love marriage" and "arranged marriage" are not binary opposites: in Bangladesh, White (2017) observes, all marriages involve both practical/economic and emotional considerations. Marriage thus links political economy and intimacy (Hunter, 2016).

Finally, marriage has also been studied as a state-regulated institution. Who can marry whom, how and under what conditions is ultimately determined through law. In recent years, geographers have examined debates about same sex marriage (e.g., Waitt, 2015; Webster et al., 2010). In some societies, states' legislative reach in relation to marriage is limited as communities reject states' legitimacy over historic practices. In India and Bangladesh, for instance, dowry payments (associated with selective abortion, female infanticide and violence towards women) persist, although they have long been outlawed. Internationally, marriage is usually seen as culturally sanctioned and consequently the prerogative of national governments: the World Bank considers it beyond the reach of direct policy intervention (White, 2017). Current campaigns for a universal minimum marriage age (e.g., UNICEF, 2014), however, reflect a view that children are a global, rather than national, responsibility and seek to universalise Western practices.

Strikingly absent from geographical work on marriage is a focus on youth. The youth of marriage partners is seldom remarked on except where the discourse of "child marriage" is invoked. Youth geographers have noted a widespread prolongation of youth associated with delayed marriage (Jeffrey, 2010a; Langevang, 2008) and the difficulties many young men face in accumulating the resources required to marry, which is a necessary precursor to "social adulthood" (Hansen, 2005; Singerman, 2013). However, little consideration has been given to the broader role marriage plays in lifecourses or in society at large. Moreover, young people's narratives of marriage have received little attention. This might partly reflect rising age at marriage and its diminishing prevalence in western societies. Yet globally marriage continues to be part of most young people's lives and geographies of youth offer useful conceptual tools to advance understanding of its role.

\section{3 | RELATIONAL GEOGRAPHIES OF AGE AND GENERATION}

Hopkins and Pain's (2007) call for a relational geographies of age stimulated new approaches to research with young people. Echoing earlier work in the "new social studies of childhood" (James et al., 1998), they argue age is not biologically or chronologically determined, but socially constructed. They cite Wyn and White:

The meaning and experience of age, and of the process of ageing, is subject to historical and cultural processes ... Both youth and childhood have had and continue to have different meanings depending on young people's social, cultural and political circumstances. (1997, p. 10) 
Space and place are significant: age(ing) has a geography.

A relational approach to age recognises that age is produced in situated interactions between people (Hopkins \& Pain, 2007). Intersecting power relations of (inter alia) gender, age and generation play out in spatially specific ways to constitute identities. Hopkins and Pain (2007) pay particular attention to intergenerationality, focusing on how young people's identities are produced through their interactions with people of other age groups and generations and are constantly in flux. These generational relations are manifest in the immediate family (e.g., parent-child relations) but also in national-level intergenerational contracts expressed through, for instance, childcare and pension policies. They involve both material and emotional aspects, which feature in intergenerational conflict. The complexities of intergenerational relations are highlighted when conventional family structures are disrupted (van Blerk \& Ansell, 2007). Hopkins and Pain (2007) also argue that lifecourses should be understood not as fixed and predictable stages, but relationally produced with fluid and situated meanings.

More recently, intergenerational relations have received attention from development studies scholars (Huijsmans, 2017; Huijsmans et al., 2014). This work focuses on how generational relationships shape society rather than individual lives and lifecourses. Economic and social development processes are understood to be conceived and implemented through practices that both rely on and reconfigure generational relations (Ansell, 2014).

A number of geographers have seized on anthropologist Johnson-Hanks' (2002) notion of "vital conjunctures" to advance the relational geographies of age and lifecourse in ways that work between the individual and the social (e.g., Esson, 2013; Evans, 2014; Jeffrey, 2010b; Langevang, 2008; Radcliffe \& Webb, 2016). Johnson-Hanks argues for an alternative way of understanding life events such as childbirth, marriage or migration, as these "are rarely coherent, clear in direction, or fixed in outcome" (2002, p. 865). Her research among educated Beti women in southern Cameroon contested the well-rehearsed idea that motherhood constitutes a clear threshold into female adulthood, revealing it to be a fluid, loosely bounded status. While in some settings her participants were understood as mothers and adults, in school they remained children. Adult status, she therefore argues, depends not on the accomplishment of a set of life events but the role one inhabits in a particular social interaction.

Instead of emphasising "vital events" bounding discrete life stages, Johnson-Hanks (2002) proposes an alternative analytic concept: the vital conjuncture. This "refers to a socially structured zone of possibility that emerges around specific periods of potential transformation in a life or lives" (2002, p. 871). She draws on Bourdieu (1977), who referred to shortterm conditions that manifest social structure and enable social action as "conjunctures". Leaving school, marriage and childbearing are responses to the potential alternative futures young people face at any moment. These "imaginable futures that are hoped for or feared" (2002, p. 878), which Johnson-Hanks terms "horizons", are socially structured and institutionally framed. When completing a degree or marrying, for instance, young people evaluate their future career, residence, reproduction and consumption. At these times, they navigate in relation to their horizons, future stakes being particularly significant. Vital conjunctures, then, are times of future orientation, extreme uncertainty and the potential for radical transformation. They are not discrete events, but have a duration that includes both the lead up to the event and a range of outcomes that occur over different subsequent timeframes. Moreover, "[w]hereas classic demographic events happen to individuals, conjunctures are distributed over social groups" (Johnson-Hanks, 2002, p. 872). Similar horizons are confronted, albeit individuals navigate different paths. The concept of the vital conjuncture lends itself to understanding the role of marriage in young people's lives in relation to social constraints and expectations.

\section{4 | MARRiage as a RELATIONAL PRACTICE}

Marriage is fundamentally relational: the lives of two individuals (generally) become profoundly entwined. Beyond providing a context for intimacy and shaping linked lifecourses, marriage is produced through and also constructs wider social relations. Notably, marriage binds together families, and the way it does so serves the generational reproduction of society.

Marriages are generally negotiated and transacted across generations. While forced marriage is unusual, older kin are often involved in marriage decisions. Elders aim to further their family interests through network building and property retention/accumulation (Oheneba-Sakyi \& Takyi, 2006). The mechanics of marriage often involve the transfer of money or resources between families and generations. "Bridewealth", for instance, may be paid by the bridegroom to the bride's parents, or "dowry" to the couple by the bride's parents. Such payments bind spouses and generations together (particularly where payments or debts persist for many years), and help secure control over reproduction, particularly where children are a crucial resource (Hunter, 2016). In some contexts, marriage produces interfamilial labour obligations known as "brideservice" (Fricke et al., 1998). Rather than rigid control, the role of these exchanges may be to introduce some ambiguity and negotiability into marriage (Comaroff, 1980). 
The familial obligations associated with marriage have significant consequences. Ability to pay (or desire to expedite or minimise payments) may shape age at marriage and also the way in which it reconfigures the relationships of age, gender and generation that sustain and shape young people's lives (Assaad \& Krafft, 2014). Marriage intervenes in the lifecourse (symbolically and empirically), usually in a transformative way. Albeit not a singular threshold to adulthood (JohnsonHanks, 2002), marriage in many societies confers important aspects of adult status. Often in African customary law, a person must be married before being allocated farmland or taking a full adult role in a community (Ansell, 2016). Marriage is, however, almost always an asymmetrical relationship with different rights and responsibilities vested in the partners and their families. Payments play a role in these asymmetries and thereby the construction of social hierarchies (Hunter, 2016). Bridewealth payments, for instance, both shape men's expectations of rights over women's sexual and reproductive capacities, and facilitate broader control over their wives (Frost \& Dodoo, 2010).

Marriage also usually ${ }^{2}$ entails the relocation of one partner to live with the other. This spatiality relates to its generational function. Most African societies are patrilineal and patrilocal meaning the couple and their offspring belong to the husband's lineage and are expected to live close to, if not reside with, his kin. Brides, therefore, must relocate. A minority of African societies are matrilineal ${ }^{3}$ and matrilocal, with heredity through the female line and husbands joining their wives' kin as "marital immigrants" (Kishindo, 2010). The spatially structured intersection of gendered and generational relations produces quite different lifecourses for young men and women, with distinctive impacts on their access to both emotional and economic resources (Kishindo, 2010; Takahashi, 2005).

Marriage arrangements both reflect and remake wider social and economic relations (Ong, 2010). Marriage may be understood, for instance, as a means by which the more powerful (men, older generations, elites) exercise control in relation to those less powerful. It helps cement social structures, ensure order and secure the future of families, but to do so, must adapt to changing socioeconomic circumstances. It is thus situated culturally but also in relation to differing social and economic circumstances.

\section{5 | MARRIAGE AS A SITUATED PRACTICE: THE SOUTHERN AFRICAN CONTEXT}

Marriage is a geographically varied phenomenon that takes different forms, means different things and is experienced in different ways in different places. Dimensions of difference include expected age at marriage, age difference between the parties, rights and obligations of the parties, roles and responsibilities of kin, payment of bridewealth or dowry, associated migration patterns, views on polygyny or polyandry, and rights to divorce (and remarriage). Moreover, the process of contracting a marriage may be formal or informal; presaged by an engagement, betrothal or period of cohabitation; and sharply demarcated from unmarried status or part of a continuum. These differences reflect historical and ongoing economic and social conditions, religious and cultural beliefs, and the ways these converge in different contexts.

Across southern Africa, marriage is produced through relations of age and generation and serves to (re)produce such relations in ways that shape individual lifecourses and broader social and economic ends. There are marked differences between the institution of marriage in rural Lesotho and in southern Malawi. Although both are subject to similar regional social and economic pressures, specific differences have emerged that partly relate to historical economic patterns, and the generational relationships required to support these.

\section{1 | Lesotho}

Like many African countries (Oheneba-Sakyi \& Takyi, 2006), Lesotho has a plural legal system with parallel marriage traditions. Rural dwellers are governed by "customary law" and expected to practise customary marriage, while those living a "modern lifestyle" are subject to different marriage laws. Customary marriage, as in most of southern Africa, is patrilineal and patrilocal. Women in rural Lesotho usually marry outside their community and move to live with their in-laws. Bridewealth (bohali) is payable, usually in instalments, by men to their in-laws, and the chief's record of this constitutes the marriage. Bridewealth requires the accumulation of substantial wealth (eight cows to start with) so men tend to marry relatively late and may be a decade older than their brides. Marriage is viewed as uniting two families and is a slow process achieved over time, rather than a single event, cemented with further payments of bridewealth, including on the birth of the first child.

Bridewealth transfers wealth between generations. It was codified in customary law in the early 20th century, influenced by colonial authorities keen to reinforce the power of elders vis-à-vis young men who earned money from South African minework. Bridewealth secured the transfer of some of this wealth to their rural communities, and bound young men more 
securely to their wives and in-laws. Murray (1977) observed the senior generation's continuing interest in this practice, while young men used it to entrench their relationship to their children and defend their own interests against those of their in-laws. Men must be married to their children's mothers for paternity to be recognised (and the child to belong to the patriline). In a nation characterised by male labour migration, marriage laws also enforced the power of absent men over resident women. Until 2006, women married under customary law were legally perpetual minors, transferred from the guardianship of their fathers to their husbands on marriage, along with "their" property and earnings. Wives' identity is further subordinated to their husbands' lineage at marriage, as their mothers-in-law bestow on them a new name in the form "mother of ...", thereby also naming their first born son. Yet despite bridewealth's role in reinforcing male power, girls may support its continuation, believing it to provide appropriate compensation to their parents for raising them (Ansell, 2001).

Marriage sustains relations of age as well as generation and gender. It is an essential precursor to adult status for most young men and women in rural Lesotho. Access to land (for farming and building a house) is traditionally granted only on marriage (recent land policy has altered the law, but practices have changed little). While land is given to men, both men and women need to be married to access land.

In parts of southern Africa, marriage rates are declining. As opportunities for male labour migration diminish, women are reluctant to marry into an unsustainable and oppressive household (Francis, 2002). Among Zulu youth the tension between the high cost of bridewealth and respect for the tradition makes marriage difficult (Posel \& Rudwick, 2014). In urban Lesotho, too, marriage rates are declining, but in rural areas young people are increasingly marrying without payment of bridewealth. Through "elopement", which may or may not be consensual, the power of the older generation is reduced by presenting marriage as a fait accompli.

\section{2 | Southern Malawi}

In much of central and southern Malawi, in contrast to most of southern Africa, rural communities are matrilineal and matrilocal (Kishindo, 2010). Men move to join their wives, although the couple commonly spend the first year or so of married life in the husband's family compound, while he establishes links in his new community and they build a house. Couples are expected quickly to become independent. Daughters are provided with land from their matrilineage, sometimes before they marry, but men generally must marry to access fields from their wives (Kishindo, 2010). (In special circumstances they may have temporary use of fields belonging to their female matrikin [Peters, 2010]).

Most rural dwellers engage in "traditional" rather than church marriages. These are not registered and may be instituted informally by a couple simply moving in together, although "marriage counsellors" sometimes brief the couple and negotiate the marriage, as well as offering advice and assistance if marital difficulties subsequently arise. The obligations between generations are less pronounced than in Basotho marriages, but a husband retains substantial responsibility toward his sisters' children as, unlike his own offspring, they belong to his birth lineage.

Matrilineal practices have a long history in southern Malawi. They were reworked by the nyau male secret society from the mid-19th century in ways that both increased male power within matrilineages and enabled the continuity of matrilocality (Kachapila, 2006). The traditions were reinforced when codified in customary law during the colonial era. Chanock (1985) argues this particular codification was designed to meet the needs of the colonial state and the African neo-traditional elite in response to the abolition of slavery, increased cash cropping, labour migration and urbanisation.

Matrilineal marriage is sometimes viewed as relatively empowering to women (see Takahashi, 2005) but has suffered a history of prejudice (Peters, 2010). Marriage in southern Malawi has, since the 1940s, been presented as an institution in crisis, perpetually compared against a mythical earlier time of greater stability (Kaler, 2001). Concerns relate to the extent of men's commitment to their marriages, their children and their marital communities. Policy-makers have, for instance, suggested men may be dissuaded from planting trees (Hansen et al., 2005) or investing in agriculture (Kishindo, 2010). A more prominent concern is that men can easily desert wives in situations where they are incomers and have relatively little vested in their marital communities and households (Kishindo, 2010). Malawi's divorce rates of 40\%-65\% are among the highest in Africa, although this could also be read as indicative of women's empowerment (Reniers, 2003). In cases of divorce, the husband leaves his wife, children, house and fields and moves back to his parents. Wives clearly retain much more than in some societies, but may lose valuable labour. It is not unheard of for men to "divorce" their wives during seasons of high agricultural labour intensity and then return to the marriage at harvest time.

Marriage in Malawi is not unchanging. Davison (1993) observed a growth in women's contribution to household agricultural production, although women continued to focus on household rather than collective (female) production to optimise their control over the benefits of household production. Age at first marriage has risen, a situation associated with extension 
of education (Manda \& Meyer, 2005). Moreover, patrilocal-patrilineal systems have replaced matrilocal-matrilineal ones in many areas, especially in the central region (Place \& Otsuka, 2001).

\section{6 | RESEARCH METHODS: UNCOVERING YOUNG PEOPLE'S PERSPECTIVES}

As noted previously, discussions of marriage arose during ethnographic research conducted in two villages. Nihelo is in Thyolo District, a densely settled but impoverished part of Malawi, with high pressure on agricultural land. Most households survive through subsistence agriculture, casual labour, petty trading and sometimes the employment of family members on nearby agricultural estates or in town. Ha Rantelali is in Lesotho's Maluti Mountains. While less poor, the community is remote and livelihood options largely confined to subsistence cultivation and livestock herding, supplemented in some cases by the wages of kin employed elsewhere.

The research was undertaken in the two villages in turn, following a similar pattern beginning with community profiling and a household survey. Participatory group activities were then organised with more than thirty people aged between 10 and 24 years old in each village over the course of several months. Groups of young people were brought together, based on criteria of age and gender, as outlined in the introduction. They met on approximately 10 occasions, either after school, at the weekend or during school holidays, to undertake a similar set of largely pre-defined activities. These included drawing mental maps of the communities; daily and weekly activity charts, and seasonal calendars; photography; guided transect walks; life maps denoting key events in the young people's lives; socio-spatial network and knowledge transfer mapping; asset mapping; problem trees; emotional storyboards; and drama and video. It is the emotional storyboards and mental maps that we draw on most heavily here, as these were the activities where marriage was most often referred to. The emotional storyboards involved young people drawing pictures representing their saddest time, their happiest time, their biggest success, their greatest disappointment, their hopes for the future and their fears for the future. For the life mapping exercise the young people drew charts that represented key events in their lives and how they were connected, as well as projections into the future. In both instances, the drawings were used to stimulate discussion among the group, focusing in part on similarities and differences.

While the participatory activities provided valuable insights into the challenges young people face and into commonalities in their experiences, they were less effective in generating individual-level empirical data or tapping into young people's individual emotional experiences (Ansell et al., 2012). Following initial analysis therefore, in-depth life history interviews were undertaken with almost all resident youth in the 18-24 age group (including most of those who had married). Even here, there was a reticence among the young people to talk explicitly about their emotions, thus deeper emotional aspects of marriage decisions and experiences are perhaps underrepresented in the research findings. These methods were supplemented by interviews with key informants and with policy-makers and practitioners from government, NGOs, UN and donors agencies, and by participatory feedback and dissemination workshops with the policy community.

As with any research among young people in impoverished communities, significant ethical considerations arose. The team was careful to ensure all participants were informed about the nature and purpose of the research, and privacy and confidentiality maintained. Research assistants were provided with training, including in working with AIDS-affected young people in sensitive ways. The project received ethical approval from Brunel University London.

\section{7 | ACCOUNTS OF MARRIAGE: PATTERNS, MOTIVATIONS AND EXPERIENCES}

In the sections below, we draw on young people's accounts from both contexts, outlining briefly the different patterns of marriage in each and then in turn examining their motivations and experiences. By contrasting the narratives of young men and women from both communities in these sections, we analyse how marriage, as a vital conjuncture, is produced through and constitutes relations of age, gender and generation in highly situated ways.

\section{1 | Patterns of marriage}

Most young women in both communities married aged 16-18 (Table 1). Thus eight of the nine 18-24-year-old women in Lesotho were married, along with two who were under 18, with comparable figures in Malawi being 19 out of 21 18-24- 
year-olds and three under 18. Among young men there was a significant difference between the two communities: only two young men in Lesotho were married, in contrast with 12 of those in Malawi. All were aged over 18. Young men in Malawi generally married in their early 20s while those in Lesotho married in their late 20s or 30s. All women resident in the Lesotho village aged over 24 had married, although two households had unmarried daughters in their 20s living in the city. Seven of the 12 married youth in Lesotho and one unmarried girl had one or more children. In Malawi, 20 young people had children, of whom one remained unmarried. One young woman in each community had separated or divorced.

\section{2 | Motivations for marriage}

The roles of generational and gender relations are not always immediately apparent in young people's accounts of their marriage decisions but nonetheless underlie their explanations. A very small number of young people said they had married for reasons that appeared to have little relation to others beyond themselves and their partner, including love or the opportunity to have sex. Even these reasons must be seen as relational, insofar as it is the social context that makes marriage the appropriate setting for emotional and physical intimacy. The majority of participants, however, evaluated marriage in relation to material needs and aspirations. In so doing they took account of diverse other relationships. This need not imply a purely instrumental perspective but perhaps echoes White's observation that the way people in Bangladesh talk about intimacy is "embodied in the material provision of resources or care, rather than abstracted in purely emotional terms" (2017, p. 259). While some marriages were responses to unplanned pregnancies and others involved spontaneous "elopement", in most cases marriage involved purposeful deliberation. All, including the apparently spontaneous, represented "vital conjunctures" (Johnson-Hanks, 2002) in which young people gave consideration to alternative possible futures. The key thread running through most accounts is that the futures under consideration were shaped by situated generational relations.

Most young women in Malawi explained their decision to marry straightforwardly in relation to poverty and hunger. For Brenda, the provocation was

just problems [...] like clothes, like sometimes when you sleep hungry, so you just think that if you get married maybe the husband will be helping you.

Similarly, Fanny said she married to access food (and was therefore unable to marry the man she would have preferred). While the trigger may have been severe poverty, these accounts reflect the generational relations that made marriage appear the appropriate response in the southern Malawi context. Young women explained that they felt their families were no longer supporting them. Parents commonly influenced decisions directly or indirectly. Some young women were under direct pressure to marry from their parents. Limnile, who felt forced to marry a man she had known only a month, explained:

I wanted to stay with my mum but she was swearing at me saying I should marry as she had been feeding me a long time, and so I had nowhere to run and so I just married that husband. (Limnile, interview)

In Malawi, impoverished parents tend to withdraw support from their daughters, particularly once they have left school, ${ }^{4}$ meaning that husbands are viewed as better providers. At this vital conjuncture, Limnile confronted structured expectations concerning the generational distribution of responsibilities. When young people reach a certain age, they cease to be considered their parents' responsibility and must depend on the resources of their own generation. This allows parents to prioritise younger children who lack alternative sources of support.

TABLE 1 Marriage patterns among the young people resident in both case study villages

\begin{tabular}{|c|c|c|c|c|}
\hline & \multicolumn{2}{|c|}{ Lesotho } & \multicolumn{2}{|c|}{ Malawi } \\
\hline & Total & Married & Total & Married \\
\hline Boys $10-17$ & 28 & 0 & 15 & 0 \\
\hline Men 18-24 & 18 & 2 & 19 & 11 \\
\hline Women 18-24 & 11 & 8 & 21 & 19 \\
\hline
\end{tabular}


In Lesotho, by contrast, marriage was seen by most young women as a cause of, rather than an answer to, poverty. The young, unmarried Lesotho girls declared of married women "those people are miserable". Nyefolo said she wanted to become a nun rather than marry and have children: in her view marriage leads to extreme poverty and hard work, because "most men around here don't work so it becomes difficult to eat". Contextually specific generational relations play a different role for these young people. While the younger generation of Basotho historically had access to income through labour migration, retrenchment from South Africa's mines in the 1990s led to a secular decline in male employment. Today it is the older generation that has resources: fields, livestock and even pensions. Parents may be more dependable providers than partners, hence for girls contemplating marriage, there may be more appealing horizons, including ongoing dependence on the older generation or (more realistically) factory work or a religious vocation.

Marriage is embedded in generational patterns not only of resource distribution but also the allocation of labour. Particularly in Malawi, where fewer assets are held by either young or old, sustenance depends more directly on physical labour in fields than in Lesotho, and the young are expected to support the elderly through work. In fact, among young men in both communities, marriage commonly reflected their responsibility to access labour for the family. Marriage was a way of playing out interdependent generational relations rather than a quest for independence (Punch, 2002). Some Malawian men valued the help their brides could contribute (albeit they would relocate before long to their wives' homes). Wyson, for instance, said he chose to get married "because my mother, it's been difficult for her, work was too much for her so I thought maybe if I can find someone to help her". Young men in Lesotho contemplated future marriages from a similar perspective. Bakoena wanted "someone to help my grandmother in her home". Letsema declared "I need someone to help me. I have lot of work to do so it will be easy when we share because my parents are getting older". He suggested, for instance, that his wife would make food for people working in their fields, as is expected when wheat is harvested. These young men represented their motives as based in care and affection for their families, rather than self-interest. As Morrison et al. (2012) argue, bodies become oriented to others through love, which is not confined to the intimacy between couples, and needs to be part of understanding relationality. Moreover, the young men were not necessarily envisaging offloading work onto their (as yet unknown) wives. Although they clearly viewed work as gendered, they too expected to work harder. This would particularly be the case as they raised their own children, and acquired responsibilities toward a new generation. On the other hand, there were some young men who said they would not want to marry, as they did not want the responsibility it entailed. As Tseane declared: "I hate supporting other people".

The significance of generational relations in marriage decisions becomes particularly clear when examining the role of AIDS in framing possible futures. Both Malawi and Lesotho have very high HIV prevalence: around half the young people involved in the research were orphans or had a chronically sick or recently deceased close family member. While sometimes manifesting in poverty and hunger, AIDS also transforms generational relations (van Blerk \& Ansell, 2007), shaping the alternative social futures that young people have to navigate. Retselisitsoe, a boy in Lesotho, felt that "with the absence of parents, I want someone who can help me". For him and some other boys, the conjugal relationship was viewed as a substitute for a generational one, providing resources that might otherwise have been expected from parents.

In Malawi, some evidence indicates that where adult mortality rises, girls tend to marry earlier (Ueyama \& Yamauchi, 2009), although research by Chae (2013) across four African countries (Burkina Faso, Ghana, Malawi and Uganda) suggests a less clear-cut relationship between AIDS and early marriage. Many Malawian women in our research said they had married early to secure assistance, which in some cases may have been attributable to AIDS. ${ }^{5}$ In a group discussion of the consequences of orphanhood, one young woman suggested that if there is no food available when children arrive home from school, they become depressed: "If you see that there is no help, you just think that it's better to be married so that you can be eating fish". As for the boys in Lesotho, the failure of cross-generational provision was seen as a reason to cement a new intra-generational relationship.

The death of a parent ruptures a generational relation and for young people represents a vital conjuncture with lasting outcomes, extending beyond the timing of marriage. Following orphanhood, the participants navigated a nexus of alternative horizons, none of which appeared ideal. At issue was not only whether or not to marry but also choice of marriage partner. Several young Malawian women had married men they might not have chosen in other circumstances. Irene, for instance, married following her father's death: "it happened as you have said for lack of assistance. I married him because he was available". Some men, too, experienced constrained options. Rex, for instance, spoke of how he "couldn't be picky" because, as an orphan from Mozambique, he had nothing to offer a wife in Malawi: "[i]f you want to buy something at the market and you don't have enough money you buy something befitting the amount of money you have". His wife, whose first husband and child had died, also had limited horizons in relation to marriage. In the social context of the village, suspicion concerning her likely HIV status reduced her own marriageability. She considered herself lucky to have attracted a new partner but also vulnerable to abandonment. 
AIDS' disruption to generational relations and the impacts on marriage were particularly clear in Lesotho, albeit less uniform. Boys in Lesotho reported needing eight cows to offer as bridewealth (a situation increasingly unsustainable given the current generational distribution of resources). Orphanhood may have denied some young men access to the resources needed for marriage: very few had married and most lacked livestock. Many of these young men worked as herders for other households to earn the cattle they would require. Of the two male participants who had married, one, Tumelo, was a double orphan. Tumelo had inherited cattle prematurely when his father died, and married five years later, paying the eight that were required. Others, such as Thabo, had negotiated with employers or foster parents an agreement to pay their bridewealth.

For orphaned girls in Lesotho, it was the absence of an older generation demanding payment that shaped their horizons. This was attractive to young men with limited resources, and several such young women had married without payment of bridewealth. Mamoletsane, for instance, indicated her husband had chosen her because he had no cattle: he could not have married a woman whose parents expected substantial bridewealth. Each lifecourse was individual and shaped by particular circumstances, but navigated in relation to common generational expectations.

While the timing of marriage and choice of partner were outcomes of navigating generational relationships in response to contemporary social and economic conditions, the expectation that marriage will figure in almost any "imaginable future" is culturally entrenched in both communities. Few Malawian men had explicit reasons for having married - for most it was simply a universal expectation. Makwete explained: "I married because I have grown up; I am supposed to find a wife." Marriage not only enables young people to navigate generational relations but is itself a product of intergenerational transmission of cultural practices. Expectations are policed through stigmatisation. If young Malawian women were (believed to be) in intimate relationships with men, they married to avoid stigma. Limnile continued her story:

Now here if you are not married people think of you as a prostitute and I accepted him to defeat that name [label] of a prostitute and I married him.

While such labelling was not applied to young men, some of those in Malawi had "had to" marry when their girlfriends became pregnant. Some regretted this as they would have preferred a different partner, but felt bound by duty. Marriage thus serves a socially necessary role, not merely in the generational relationships between young people and their parents, but also as the near-compulsory context for raising the next generation. Often in Africa marriages are deemed meaningless without children (Oheneba-Sakyi \& Takyi, 2006). Indeed, marriage was associated by many participants with having children. If not synonymous, some young people suggested they would marry in order to have children while a small number of mainly young men said they would reject marriage because they did not want them.

Social control over marriage is not, however, total. A number of young people resisted the control exerted through family and community expectations. Some men refused to marry their pregnant girlfriends, leaving the costs to the young woman. Others married in spite of adult advice. As Julita revealed: "we, the youth, are easily carried away ... When parents try to advise you, it doesn't sound a thing, in the end you just get married". Others indicated their marriages were neither conformist nor resistant but spontaneous and unpremeditated. Tseliso insisted he "didn't have valid reasons. I was just stubborn ... I just married her because she was there." Thus other generations almost invariably play a role in shaping whether, when and whom young people marry, but the actual paths taken are not determined.

\section{3 $\mid$ Experiences of marriage}

Marriage plays a part in young people's lifecourses that differs significantly depending on both gender and the prevalent social and spatial relations of marriage, including the generational structures and broader social and economic circumstances. Very different narratives of married life were presented by young men and women in the two countries.

Many of the Malawian women, asked to depict the happiest moment of their lives in their emotional storyboards, represented their marriages. Almost universally, they were pleased to have married, and felt their lives had improved as a consequence. Even Limnile, who described having been pushed into marriage by her parents, was very positive about the outcome.

How has your life changed after getting married?

It has changed for the better ... Even in the beginning, if it was like this, I would have said Lord thank you. Because now, I can't lie to you, the way the times are, I have a healthy life, very much. (Limnile, interview) 
It was material changes that many noted. Several Malawian women said hunger had diminished and they now had a change of clothes. Marriage gave these young women access to resources, both from their husbands and joint resources (including fields) allocated on marriage. By contrast, the Basotho women commented on deteriorating material circumstances. Mapoka, for instance, complained that "sometimes you stay without shoes". The difference was partly attributable to how economic change impinged on the two societies, with generationally differentiated effects. Diminished opportunities for mine work left young Basotho men unable to provide generously for their wives. In absolute terms, the Basotho women were probably better off than their Malawian peers, but their husbands could not live up to the expectations set by previous generations. This was exacerbated by their status as newcomers in a patrilocal system which accorded them little claim on household resources. Bina Agarwal (1997) notes similar distinctions between patrilineal and matrilineal Indian societies, patrilocal practices engendering greater gender inequalities in intra-household resource allocation.

The spatial and generational relations of marriage are key to the very different experiences of young women in the two settings. For young women in Lesotho, having to move to new households and communities was challenging.

How do you find it to live here and to stay with a new family?

It is bad.

Why?

Everything is different and new.

So your new in-laws are not trying their best to make you feel welcome?

They are trying; I am just not happy.

Were you more afraid when you came here to get married than when you went to Maseru to work?

When I got married. (Mathabo life map)

Generationally structured dependencies differ between the two settings. In Lesotho the couple were expected initially to reside with their in-laws. Rather than marriage marking entry into full adulthood, for young Basotho women it heralded a shift from dependence on their parents to dependence on their in-laws. As young wives (makoti in Sesotho), they were not considered fully adult. Moreover, with husbands typically 5-10 years older than their wives, power relations of both age and generation constructed marriage as an unfavourable lifecourse event.

Differing generational relations of marriage also played out in the work expected of young wives. Many Malawian women reported a diminution of workload, often a result of the labour their husbands contributed to their fields. Some stopped working entirely, and relied on their husbands' contributions. Brenda celebrated: "Things have changed because I don't work anymore, I just stay." Agnes had sold buffalo beans prior to marriage to support herself, but was able to stop when she married. Others enjoyed working together and making plans together. The couples were usually similar in age, and lived and worked as a distinct conjugal unit, which perhaps led to a greater sense of partnership than in Lesotho.

By contrast, all of the Basotho makoti complained that marriage resulted in hard work. Mapoka explained that her parents had previously provided for her, but in her new home, if she had no soap she had to work hard to get it. The young women's activity calendars indicated never-ending work: from waking in the morning they swept, cooked, fetched water, went to the fields, staying there all day. On their return they again fetched wood and water, fed the chickens, cooked and ate before sleeping. This pattern was enforced by the gaze of their mothers-in-law. Young men being unable to make a significant material contribution to the older generation, daughters-in-law were expected to provide their labour. Residing with their in-laws reinforced interdependencies between the generations, but these interdependencies were highly gendered. Neither husbands nor in-laws helped with housework, a situation that the young women particularly resented as their husbands were contributing little to their households.

Do you feel that, since you have been married, are you working more now?

We are working extremely hard, we have got no time to rest.

So your husbands, what are they doing to help?

They don't do anything they just sit down and watch us. (Young women, activity calendars)

Most young people in Malawi celebrated the independence they gained from their parents when they married. Maria, a Malawian, said she and her husband had more food than was available at her parents' home and importantly it was their own food and not under someone else's control. The adulthood that marriage conferred, and independence from an older 
generation, felt liberating. By contrast, the Lesotho women had entered their in-laws' households as junior members, with obligations but, as Maselloane complained, "no freedom".

The spatial and generational structuring of marriage also shaped its role in young men's lifecourses in ways that differed between the contexts, although the differences were somewhat less marked. Matrilocal residence could cause practical problems for Malawian married men whose position as newcomers to the village made it difficult to secure casual work from neighbours. Married life therefore usually began in the husband's village for a year or two, while the couple started cultivating the fields at the wife's village and building a house. This eased the transition for the young men who could continue to cultivate irrigated plots (dimbas) and make use of networks in their natal village. Jackson explained that he remained in his natal village

because I'm recently married, so it will be hard for me to survive at my wife's place at the early stage like this, and here I have friends who can invite me for ganyu (casual work) rather than that side [where I don't].

The young Malawian men, like the women, talked of sharing work. Most described a sense of purpose that the responsibilities of marriage gave them. Makwete declared:

My life has changed, the way I walked has changed, and also my domestic chores because in the past I was just walking aimlessly.

Marriage was for them a transformational lifecourse event that contributed to an adult identity in which they exercised responsibilities. Some, however, resented the additional work which disrupted their plans, particularly where they had felt they had to marry because they had fathered a child, incurring new generational responsibilities.

I could study before getting married but this [the marriage] seemed to disturb me. I was busy looking for piece work to assist my family and so the problems became worse. (Edison, interview)

Very few of the male participants in Lesotho had yet married. Tseliso, one of those who had, suggested it was not easy:

Married life is very hectic life because you have to provide for two, unlike first when I had to look after myself alone. Now I have to buy nice clothes for my wife because a woman cannot have few clothes like a man ... I find married life very difficult because I have to work hard so that my wife looks presentable.

In both countries, there are social expectations associated with marriage that require men to make a significant financial contribution, supporting their wives. Tseliso's concern was less that his wife should be happy (he appeared puzzled when asked whether she liked clothes); rather he should be seen to fulfil his obligation as a husband through the appearance of her attire. More significantly, as children are born, men are expected to take financial and social responsibility for the next generation.

While the multiple relationalities of marriage shaped these early experiences, their impacts on young people's lifecourses extend into the longer term and perceived future prospects. Basotho makoti felt that their opportunities had diminished with marriage and envisaged limited possibilities for future improvement in their livelihoods. Their husbands were almost universally unemployed. Unless they had married a firstborn son, they were unlikely to be transferred much land by the older generation. Their own prospects were restricted by patrilocal residence: their husbands or in-laws expected them to cultivate their fields and would not generally permit them to pursue education or employment away from home. The social structuring of marriage thus impinged on their horizons in unfavourable ways.

The Malawian women's fears for the future related to the possibility of divorce. Some had been abandoned by their husbands, a situation that left them vulnerable to poverty, especially if they now had children to support. Without a husband, their responsibilities to the future generation would be hard to fulfil. This prospect loomed in many young married women's envisaged potential futures: another socially structured horizon impinging on their lives in the present. Emily depicted her greatest fear on her emotional storyboard by drawing how she would poison herself should her husband leave her. She stated: "lack of money and unstable relationship such that you change husbands now and then, it's when I can commit suicide". Her narrative indicates clearly the entwining of material and emotional aspects of marriage (White, 2017). While marriage may help young women secure immediate needs, it can also make them very vulnerable and this shapes their ongoing experience. 
Divorce and abandonment were less common in Lesotho, in part because the greater formality and economic bond of bridewealth entrenched them more securely. Where bridewealth had not been paid, it was possible to return to the natal home. Malast, for instance, who married for love at 16, found that her husband refused to involve her in decisions. When they moved to live with his mother in the small town of Roma, he was unable to find work and she struggled to undertake casual work to support herself and her children. After around eight years, he abandoned her. Because he had paid no cattle to her parents, she was able to return to her mother's home. In cases where cattle need to be returned, problematic or abusive marriages are much harder to escape. If a woman's parents have "eaten" (literally or metaphorically) the cattle, and cannot refund the husband, they may refuse to accept her back. She will also find it very hard to remarry.

\section{8 | CONCLUSIONS}

Marriage is a near-universal feature of youth in many societies worldwide, and has important impacts on individual and collective life. For this alone it merits greater attention. It also exemplifies and illuminates processes in which youth geographers are interested. In particular, a focus on marriage reveals the significance of spatiality in the construction of relations of age and generation and of the lifecourse.

First, marriage is significant in understanding the instrumental role of youth in cementing and transforming generational relations (Huijsmans, 2017). In Lesotho and Malawi, marriage plays a key part in transfers of resources and allocation of labour between generations. There are entrenched social expectations governing such transfers that in part reflect historic economic situations and shape the possible "social futures" (Johnson-Hanks, 2002) open to young people. Marriage can be undertaken as a means of accessing resources or labour but it also entails responsibilities, not only to a spouse but to other generations. As economic change shifts relative access to resources between different generations, and AIDS ruptures generational relationships (van Blerk \& Ansell, 2007), young people must navigate social, economic and emotional considerations in deciding whether and whom to marry.

Marriage represents in particular a spatial structuring of power-laden generational relations. This spatiality determines some of its gendered material and labour-related impacts. Systems of patrilocality and matrilocality disrupt the social networks of young women in Lesotho and men in Malawi, reducing their livelihood opportunities. However, it is the Basotho makoti, in unfamiliar homes, that are particularly disempowered through spatially structured relations of gender, age and generation, rendered unable to command resources, required to undertake a disproportionate share of work and denied opportunities of education or employment. It is important to recognise these power geometries that shape whether, when and whom young people (choose to) marry and their experiences of married life.

A focus on marriage also contributes to a more nuanced and specific understanding of the role of spatiality in constructing relational geographies of age. We add to the growing geographical literature that employs Johnson-Hanks' (2002) notion of the "vital conjuncture", showing that these are not merely more deeply historically embedded (particularly in postcolonial contexts) than usually construed (Radcliffe \& Webb, 2016), but also products of distinct spatialities. While, for instance, Evans (2014) explores the role of spatial context in the construction of a vital conjuncture, we identify the significance of the spatial expression of the relationships through which such conjunctures are produced.

Second, understood as a vital conjuncture, marriage is a process that constructs lifecourses relationally. Many participants described how marriage had transformed aspects of their lives including material wellbeing, workload and independence from older generations. It also shaped the opportunities available to them and gave them new responsibilities. However, it did not represent a singular threshold to adulthood, nor did the adulthood it presaged mean the same in each setting. As Hopkins and Pain (2007) suggest, age is produced relationally, in situated interactions between different people. Age and lifecourse were constructed through marriage in different and gendered ways in the two different communities. The young wives in Lesotho crossed a significant threshold on marriage, but their status was very different to that both of their husbands and of the young wives in Malawi. As a vital conjuncture, marriage constructs age and adulthood in contextually specific ways.

Marriage, then, is not a universally homogeneous practice: its shape and meaning are fluid. Its different elements - economic transaction, relocation, social incorporation - operate differently in different settings. It needs to be understood in relation to other institutions, economies and meanings (Hunter, 2016). Marriage practices reflect not only entrenched cultural expectations but also contemporary economic processes. There are sharp geographical differences, even within southern Africa, that relate to historical and contemporary contexts, are expressed spatially in different ways, and intersect with social relations of kinship and community to generate very different attitudes and experiences among the young people involved.

The crux of this paper is that marriage is highly contextual and culturally specific. We advocate that those working at a global policy level take account of this before pressing for universal policies based on western ideals, particularly where 
other aspects of poverty or rural life are not addressed or considered. Our unsettling of universalist notions of marriage raises particular questions in relation to international efforts toward a universal ban on marriage below the age of 18 . If "child marriage" is not a singular phenomenon, a more nuanced approach is needed. Many of our participants married at 16 or 17 , and while some, irrespective of age at marriage or gender, found marriage disabling, others viewed it in very positive terms. The determining factor was not their chronological age at marriage but rather the power-laden social relations within which the marriage took place and that it sustained, which differed markedly between the two communities.

\section{ACKNOWLEDGEMENTS}

This research was funded under the joint ESRC-DFID funding scheme, contract RES-167-25-0167. We are grateful to all those who gave generously of their time in support of the project: members of the Institute of Southern African Studies, National University of Lesotho, and Department of Geography and Earth Sciences, Chancellor College, University of Malawi; the project's National Steering Groups in Malawi and Lesotho; our research assistants, translators, and transcribers; and the young people and adults of Nihelo and Ha Rantelali, and all those who were interviewed for this research. We also acknowledge the helpful comments of three anonymous referees and the Editors of Transactions.

\section{ENDNOTES}

${ }^{1}$ Although the mandate of the journal Children's Geographies is to publish research about young people under 25, the word "marriage" does not appear in the title, abstract or keywords of a single article.

${ }^{2}$ In some societies couples may never cohabit.

${ }^{3}$ A small number are bilineal, both lines of descent being important.

${ }^{4}$ In both countries marriage tended to follow soon after young people left school. Most 10-17-year-olds in both communities were still attending school and unmarried; most aged 18-24 had left school and (with the exception of young men in Lesotho) were married. However, few left school in order to marry. Usually, soon after the parental function of resourcing education had ended, the generational responsibility of a parent to provide for their child was brought to a close.

${ }^{5}$ Of the eight aged 17 or over whose fathers had died, six said they married because they needed assistance. This was, however, also true of four of the eight young women whose fathers were alive. Most young women were expected to be independent of their parents' generation soon after leaving school, thus the effect of orphanhood in this context was perhaps more limited than in Lesotho.

\section{REFERENCES}

Ansell, N. (2001). "Because it's our culture!" (Re)negotiating the meaning of lobola in Southern African secondary schools. Journal of Southern African Studies, 27, 697-716.

Ansell, N. (2014). Generationing development: A commentary. European Journal of Development Research, 26, $283-291$.

Ansell, N. (2016). Children, youth and development. London, UK: Routledge.

Ansell, N., Hajdu, F., van Blerk, L., \& Robson, E. (2012). Learning from young people about their lives: Using participatory methods to research the impacts of AIDS in southern Africa. Children's Geographies, 10, 169-186.

Archambault, C. S. (2011). Ethnographic empathy and the social context of rights: "Rescuing" Maasai girls from early marriage. American Anthropologist, 113, 632-643.

Assaad, R., \& Krafft, C. (2014). The economics of marriage in North Africa. WIDER Working Paper No. 2014/067, United Nations University.

Balabdaoui, F., Bocquet-Appel, J.-P., Lajaunie, C., \& Rajan, S. (2001). The effects of migration and work on marriage of female garment workers in Bangladesh. International Journal of Population Geography, 7, 91-104.

Bina Agarwal, B. (1997). "Bargaining" and gender relations: Within and beyond the household. Feminist Economics, 3, 1-51.

van Blerk, L., \& Ansell, N. (2007). Alternative caregiving in the context of HIV/AIDS in southern Africa: Complex strategies for care. Journal of International Development, 19, 865-884.

Bourdieu, P. (1977). Outline of a theory of practice. Cambridge, UK: Cambridge University Press. https://doi.org/10.1017/CBO9780511812507

Chae, S. (2013). Timing of orphanhood, early sexual debut, and early marriage in four sub-Saharan African countries. Studies in Family Planning, 44, 123-146.

Chanock, M. (1985). Law, custom and social order: The colonial experience in Malawi and Zambia. Cambridge, UK: Cambridge University Press.

Coleman, D. A., \& Haskey, J. C. (1986). Marital distance and its geographical orientation in England and Wales, 1979. Transactions of the Institute of British Geographers, 11, 337-355.

Comaroff, J. L. (Ed.) (1980). The meaning of marriage payments. London, UK: Academic Press.

Davison, J. (1993). Tenacious women: Clinging to Banja household production in the face of changing gender relations in Malawi. Journal of Southern African Studies, 19, 405-421.

Delprato, M., Akyeampong, K., Sabates, R., \& Hernandez-Fernandez, J. (2015). On the impact of early marriage on schooling outcomes in SubSaharan Africa and South West Asia. International Journal of Educational Development, 44, 42-55. 
Esson, J. (2013). A body and a dream at a vital conjuncture: Ghanaian youth, uncertainty and the allure of football. Geoforum, 47, 84-92.

Evans, R. (2014). Parental death as a vital conjuncture? Intergenerational care and responsibility following bereavement in Senegal. Social and Cultural Geography, 15, 547-570.

Fan, C., \& Huang, Y. (1998). Waves of rural brides: Female marriage migration in China. Annals of the Association of American Geographers, $88,227-251$.

Fan, C. C., \& Li, L. (2002). Marriage and migration in transitional China: A field study of Gaozhou, western Guangdong. Environment and Planning A, 34, 619-638.

Favara, M., Lavado, P., \& Sanchez, A. (2016). Understanding teenage fertility, cohabitation, and marriage: The case of Peru. IZA Discussion Paper No. 10270.

Francis, E. (2002). Gender, migration and multiple livelihoods: Cases from eastern and southern Africa. Journal of Development Studies, 38, $167-190$.

Fricke, T., Thornton, A., \& Dahal, D. R. (1998). Netting in Nepal: Social change, the life course, and brideservice in Sangila. Human Ecology, 26, 213-237.

Frost, A. E., \& Dodoo, F. N.-A. (2010). "The man comes to marry the woman": Exploring adolescent boys' gendered expectations for bridewealth and marriage among the Akwapim of Southern Ghana. Marriage and Family Review, 46, 41-59.

Girls Not Brides. (2016). Child marriage and the law. Retrieved from http://www.girlsnotbrides.org/child-marriage-law (accessed 3 July 2016)

Hansen, K. T. (2005). Getting stuck in the compound: Some odds against social adulthood in Lusaka. Zambia Africa Today, $51,3-16$.

Hansen, J. D., Luckert, M. K., Minae, S., \& Place, F. (2005). Tree planting under customary tenure systems in Malawi: Impacts of marriage and inheritance patterns. Agricultural Systems, 84, 99-118.

Hopkins, P., \& Pain, R. (2007). Geographies of age: Thinking relationally. Area, 39, 287-294.

Huijsmans, R. (Ed.) (2017). Generationing development: A relational approach to children, youth and development. Basingstoke: Palgrave.

Huijsmans, R., George, S., Gigengack, R., \& Evers, S. J. T. M. (2014). Theorising age and generation in development: A relational approach. European Journal of Development Research, 26, 163-174.

Hunter, M. (2016). Introduction: New insights on marriage and Africa. Africa Today, 62, vii-xv.

James, A., Jenks, C., \& Prout, A. (1998). Theorising childhood. Oxford: Polity Press.

Jeffrey, C. (2010a). Timepass: Youth, class, and time among unemployed young men in India. American Ethnologist, 37, 465-481.

Jeffrey, C. (2010b). Geographies of children and youth I: Eroding maps of life. Progress in Human Geography, 34, 496-505.

Johnson-Hanks, J. (2002). On the limits of the life cycle in ethnography: Toward a theory of vital conjunctures. American Anthropologist, 104, 865-880.

Kachapila, H. (2006). The revival of nyau and changing gender relations in early colonial central Malawi. Journal of Religion in Africa, 36, 319-345.

Kaler, A. (2001). "Many divorces and many spinsters": Marriage as an invented tradition in Southern Malawi, 1946-1999. Journal of Family History, 26, 529-556.

Kandiyoti, D. (1988). Bargaining with patriarchy. Gender and Society, 2, 274-290.

Kishindo, P. (2010). The marital immigrant, land, and agriculture: A Malawian case study. African Sociological Review, 14, 89-97.

Kudo, Y. (2015). Female migration for marriage: Implications from the land reform in rural Tanzania. World Development, 65 , 41-61.

Langevang, T. (2008). "We are managing!" Uncertain paths to respectable adulthoods in Accra, Ghana. Geoforum, 39, $2039-2047$.

Levi-Strauss, C. (1969). The elementary structures of kinship. Boston, MA: Beacon Press.

Manda, S., \& Meyer, R. (2005). Age at first marriage in Malawi: A Bayesian multilevel analysis using a discrete time-to-event model. Journal of the Royal Statistical Society Series A: Statistics in Society, 168, 439-455.

Maswikwa, B., Richter, L., Kaufman, J., \& Nandi, A. (2015). Minimum marriage age laws and the prevalence of child marriage and adolescent birth: Evidence from sub-Saharan Africa. International Perspectives on Sexual and Reproductive Health, 41, 58-68.

Mohammad, R. (2015). Transnational shift: Marriage, home and belonging for British-Pakistani Muslim women. Social and Cultural Geography, $16,593-614$.

Morrison, C.-A., Johnston, L., \& Longhurst, R. (2012). Critical geographies of love as spatial, relational and political. Progress in Human Geography, 37, 505-521.

Morrow, V., \& Crivello, G. (2015). What is the value of qualitative longitudinal research with children and young people for international development?. International Journal of Social Research Methodology, 18, 267-280.

Murray, C. (1977). High bridewealth, migrant labour, and the position of women in Lesotho. Journal of African Law, 21, 79-96.

Oheneba-Sakyi, Y., \& Takyi, B. K. (Eds) (2006). African families at the turn of the 21st century. Westport, CT: Praeger.

Ong, A. (2010). Spirits of resistance and capitalist discipline: Factory women in Malaysia. Albany, NY: Suny Press.

Pankhurst, A., Tiumelissan, A., \& Chuta, N. (2016). The interplay between community, household and child level influences on trajectories to early marriage in Ethiopia: Evidence from Young Lives. Young Lives Working Paper No. 162.

Peters, P. E. (2010). "Our daughters inherit our land, but our sons use their wives' fields": Matrilineal-matrilocal land tenure and the New Land Policy in Malawi. Journal of Eastern African Studies, 4, 179-199.

Place, F., \& Otsuka, K. (2001). Tenure, agricultural investment, and productivity in the customary tenure sector of Malawi. Economic Development and Cultural Change, 50, 77-99.

Posel, D., \& Rudwick, S. (2014). Marriage and bridewealth (Ilobolo) in contemporary Zulu society. African Studies Review, 57, 51-72.

Punch, S. (2002). Youth transitions and interdependent adult-child relations in rural Bolivia. Journal of Rural Studies, 18, 123-133. 
Radcliffe, S., \& Webb, A. (2016). Mapuche youth between exclusion and the future: Protest, civic society and participation in Chile. Children's Geographies, 14, 1-19.

Reniers, G. (2003). Divorce and remarriage in rural Malawi. Demographic Research, 9, 175-206.

Roest, J. (2016). Child marriage and early child-bearing in India: Risk factors and policy implications. Young Lives Policy Paper 10.

Safa, H. I. (1999). Free markets and the marriage market: Structural adjustment, gender relations, and working conditions among Dominican women workers. Environment and Planning A, 31, 291-304.

Shapiro, D., \& Gebreselassie, T. (2014). Marriage in Sub-Saharan Africa: Trends, determinants, and consequences. Population Research and Policy Review, 33, 229-255.

Singerman, D. (2013). Youth, gender, and dignity in the Egyptian uprising. Journal of Middle East Women's Studies, 9, 1-27.

Takahashi, M. (2005). Marriage, gender, and labor: Female-headed households in a rural Cambodian village. Southeast Asian Studies, 42, 442463.

Thomas, L., \& Cole, J. (2009). Thinking through love in Africa. In J. Cole \& L. Thomas (Eds), Love in Africa. Chicago, IL: University of Chicago Press. https://doi.org/10.7208/chicago/9780226113555.001.0001

Tiano, S., \& Ladino, C. (1999). Dating, mating, and motherhood: Identity construction among Mexican maquila workers. Environment and Planning $A, 31,305-325$.

Torabi, F., Baschieri, A., Clarke, L., \& Abbasi-Shavazi, M. J. (2013). Marriage postponement in Iran: Accounting for socio-economic and cultural change in time and space. Population, Space and Place, 19, 258-274.

Ueyama, M., \& Yamauchi, F. (2009). Marriage behavior response to prime-age adult mortality: Evidence from Malawi. Demography, 46, 43-63.

UNICEF. (2014). Child marriage. Retrieved from http://www.unicef.org/protection/57929_58008.html (accessed 3 July 2016).

Waitt, G. (2015). I do? On geography, marriage and love in Australia. Australian Geographer, 46, 429-436.

Webster, G. R., Chapman, T., \& Leib, J. (2010). Sustaining the "societal and scriptural fence": Cultural, social, and political topographies of same-sex marriage in Alabama. Professional Geographer, 62, 211-229.

White, S. C. (2017). Patriarchal investments: Marriage, dowry and the political economy of development in Bangladesh. Journal of Contemporary Asia, 47, 247-272.

Wyn, J., \& White, R. (1997). Rethinking youth. London, UK: Sage.

Yeoh, B. S. A., Chee, H. L., \& Vu, T. K. D. (2014). Global householding and the negotiation of intimate labour in commercially-matched international marriages between Vietnamese women and Singaporean men. Geoforum, 51, 284-293.

Zhang, J., Lu, M. C.-W., \& Yeoh, B. S. A. (2015). Cross-border marriage, transgovernmental friction, and waiting. Environment and Planning D: Society and Space, 33, 229-246.

How to cite this article: Ansell N, Hajdu F, van Blerk L, Robson E. "My happiest time" or "my saddest time"? The spatial and generational construction of marriage among youth in rural Malawi and Lesotho. Trans Inst Br Geogr. 2018;43:184-199. https://doi.org/10.1111/tran.12211 